\title{
Službenici u Bosni i Hercegovini 1878. - 1918.
}

\author{
TOMASZ JACEK LIS \\ Wyższa Szkoła Kultury Społecznej i Medialnej \\ Toruń, Poljska \\ tomlis88@gmail.com
}

U radu se analizira austrougarska civilna uprava u Bosni i Hercegovini od 1878. do 1918. godine. Ipak, nije riječ o instituciji nego o službenicima, često strancima, koji su ondje radili. Činovnici višega i nižega reda bili su odgovorni za provođenje svih odluka koje su donijeli političari u Beču ili Sarajevu. Oni su bili mostovi koji su spajali stanovnike Bosne i Hercegovine sa Zemaljskom vladom. U članku će se razmatrati njihov položaj u zemlji te njihov rad, ali i svakodnevni život jer su oni bili nova elita koja je modernizirala Bosnu i Hercegovinu na prijelazu iz XIX. u XX. stoljeće.

Ključne riječi: Bosna i Hercegovina; austrougarska okupacija; činovnici; zajedničko Ministarstvo financija; Zemaljska vlada u Sarajevu

Učinkovita javna uprava bila je preduvjet normalnoga funkcioniranja moderne države. Stoga su u drugoj polovini XIX. stoljeća politička moć i gospodarsko blagostanje europskih država bili nezamislivi bez javne uprave sačinjene od brojnih, dobro školovanih i iskusnih činovnika. Nije bilo drugačije ni u Bosni i Hercegovini, gdje bez modernih službenika nije bila moguća integracija toga nekadašnjega osmanskog vilajeta u zapadnoeuropski civilizacijski krug. Austrougarske modernizacijske procese (napredak infrastrukture, školstva, zdravstva) pratio je porast stanovništva kao najbolji pokazatelj povećanja blagostanja, a istovremeno je rastao broj službenika koji su provodili odluke moderne države, tj. Zemaljske vlade u Sarajevu. Taj složeni upravni aparat 
oslanjao se na stotine, poslije tisuće činovnika višega i nižega razreda, koji su provodili i odgovarali za modernizaciju zemlje. ${ }^{1}$

Intenzitet modernizacijskih mjera Austro-Ugarske u Bosni i Hercegovini od 1878. do 1918. može se ilustrirati usporedbom sa susjednim balkanskim nacionalnim državama Crnom Gorom i Kraljevinom Srbijom. Pritom se vidi sav opseg posla koji je učinio austrougarski upravni aparat, o čemu su govorili suvremenici i na zapadu (Francuska, Engleska, Njemačka)² i u Dvojnoj Monarhiji (npr. u Galiciji) ${ }^{3}$. Uspostava novoga upravnog aparata bila je za austrougarske vlasti veliki izazov, pa su bile potrebne goleme ljudske i financijske žrtve da se nadvladaju problemi i ustroje sve potrebne službe. Najveći problem s kojim se Zemaljska vlada u Sarajevu morala suočiti prvih godina okupacije Bosne i Hercegovine bili su kadrovi jer je u okupiranim pokrajinama nedostajalo ljudi sa stručnim kvalifikacijama zapadnoeuropske naobrazbe sveučilišnoga i srednjoškolskoga tipa. Isključenje lokalne elite nije dakle uslijedilo zbog nepovjerenja, nego zbog nemogućnosti suradnje s novim vlastima, koje su za lokalne prilike tražile nova znanja. Kako se člankom 25. Berlinskoga ugovora Austro-Ugarska obvezala verwaltet werden Bosnom i Hercegovinom te dvije riječi natjerale su nove vlasti na naglo zapošljavanje stranaca, koji su popunili sve upravne položaje u središnjim i mjesnim upravnim strukturama. ${ }^{4}$

Nekoliko je čimbenika utjecalo na takav razvoj događaja. Na početku valja napomenuti da se Osmansko Carstvo u Bosanskom vilajetu nije oslanjalo na zapadnoeuropski nego na vlastiti model uprave, pa nakon 1878. i nije bilo upravnoga aparata i činovnika koje bi mogla „preuzeti” nova vlada. Radna praksa osmanske birokracije razlikovala se od standarda javne uprave koji su vladali u Austro-Ugarskoj Monarhiji. Osim toga, odlaskom dijela nezadovoljnoga muslimanskog pučanstva nakon okupacije smanjio se brojčani potencijal muslimanskoga kadra jer su čak i oni muslimani koji bi za standarde novoga sustava bili dobro obrazovani i time prihvatljivi za činovničku službu potražili

\footnotetext{
1 PALAIRET, „The Habsburg Industrial Achievement in Bosnia-Hercegovina”, 133-152; HAUPTMANN, „Privreda i društvo Bosne i Hercegovine u doba austrougarske vladavine”, 99-211; HADŽIBEGOVIĆ, Postanak radničke klase u BiH, 100-102; HADŽIBEGOVIĆ, Bosanskohercegovački gradovi na razmedu 19. i 20. stoljeća, 50-67; SUGAR, Industrialization of Bosnia-Hercegovina, 27-32; OKEY, Taming Balkan Nationalism, 65-67; SCHMID, Bosnien und die Herzegovina unter der Verwaltung Österreich-Ungarns, 50-75.

2 ŽMIRIĆ, Austrijski i njemački putopisi o Bosni i Hercegovini do 1941 godine; ŠAMIĆ, Francuski putnici u Bosni na pragu XIX stoljeća i njihovi utisci o njoj; HADŽISELIMOVIĆ, Na vratima Istoka: engleski putnici u Bosni i Hercegovini od 16 do 20 veka.

3 LIS, „Bosna i Hercegovina u očima Poljaka - poljski putopisi o Bosni i Hercegovini u austrougarskom razdoblju”, 91-105.

4 RUBACHA, MALINOWSKI, GIZA, Historia Bułgarii 1870-1915, 27.
} 
sreću u Osmanskom Carstvu. ${ }^{5}$ Naravno, postojale su i određene iznimke, pa na funkciji prvoga sarajevskoga gradonačelnika u novim prilikama nalazimo Mustaj-bega Fadilpašića (1878. - 1892.) ${ }^{6}$, a gradski mjernik Huršid ef. Teresinski bio je prvi načelnik vatrogasaca u Sarajevu (1883. ${ }^{7}$. Američki povjesničar Peter F. Sugar procijenio je broj školovanih ljudi koji su htjeli surađivati s upravom na malo više od 120 osoba, ne dijeleći ih pritom po vjeri ili naciji. ${ }^{8}$ Nažalost, ne piše više o tome, pa se ne znaju njihova zanimanja, jesu li bili službenici višega ili nižega razreda. To je dakle bio ljudski kapital Bosne i Hercegovine uoči aneksije.

Povjesničari u komunističkoj Jugoslaviji često su tvrdili da Austro-Ugarska nije željela zapošljavati Hrvate i Srbe iz Monarhije odnosno kada je to i činila, za njih su pretežno bila rezervirana mjesta činovnika nižega razreda ili dnevničara. Tako je Tomislav Kraljačić napisao: „[...] ako se pogledaju mjesta koja su zauzimali u administraciji [muslimani, Srbi, Hrvati, op. T. J. L.], vidjeće se da su to bili najniži položaji." " Kao dokaz je iznio statistiku činovnika iz 1902., gdje postoji podatak da je ukupno bilo 8343 službenika, od čega 2191 iz Bosne i Hercegovine, 2874 iz Austrije, 3253 iz Mađarske i 25 iz drugih zemalja. Ipak, ne govori koliko je bilo Hrvata i Srba koji nisu bili domaći, nego su u Bosnu i Hercegovinu došli iz Austrije i Mađarske (Dalmacija, Vojvodina, Slavonija itd.), pa ta statistika nije dokaz da su Južni Slaveni bili u manjini. Štoviše, u statistici činovnika za 1907. godinu Srba, Hrvata i muslimana bilo je 5576, a Nijemaca i Mađara 1511;10 1908. godine Srba, Hrvata i muslimana bilo je 5771, a Nijemaca i Mađara 1476;1' neposredno pred rat 1914. u izvještaju ne postoji rubrika o nacionalnosti nego o jeziku, gdje stoji da ima 9438 činovnika kojima je materinji jezik srpsko-hrvatski, za 1569 njemački, a za 334 činovnika mađarski. ${ }^{12}$ Osim neprecizne statistike, srpski historičar kao dokaz je naveo Kállayevo pismo barunu Isidoru Benku, gdje zajednički ministar kaže da je opasno zaposliti Hrvate jer oni podupiru hrvatski nacionalizam, kao što uostalom i Srbi podupiru srpski. ${ }^{13}$ U tome je imao pravo, a dobar su primjer

\footnotetext{
KAMBEROVIĆ, Begovski zemljišni posjedi, 73; DONIA, Islam under the Double Eagle; HADŽIBEGOVIĆ, „Migracije stanovništva u Bosni i Hercegovini”, 313-316.

DONIA, Sarajevo: A Biography, 42.

KREŠEVLJAKOVIĆ, Sarajevo za vrijeme austrougarske uprave, 35.

8 SUGAR, Industrialization of Bosnia-Hercegovina, 29; GLUCK, Sarajewo (historia zamachu sarajewskiego), 40.

$9 \quad$ KRALJAČIĆ, Kalajev režim u Bosni i Hercegovini, 439.

10 Bericht über die Verwaltung von Bosnien und der Hercegovina 1907, 7.

11 Bericht über die Verwaltung von Bosnien und der Hercegovina 1908, 5.

12 Bericht über die Verwaltung von Bosnien und der Hercegovina für die Jahre 1914-1917, 178.

13 KRALJAČIĆ, Kalajev režim u Bosni i Hercegovini, 440.
} 
učitelji iz Vojvodine, koji su širili srpski nacionalizam u školama. ${ }^{14}$ Ipak, prema mom mišljenju, mnogo važniji uzrok niska udjela Hrvata, Srba i muslimana u činovništvu u Bosni i Hercegovini jest to što je među njima u doba okupacije i sljedećih godina jednostavno postojao vrlo tanak sloj dobro obrazovanih ljudi.

Činovnik u austrougarskoj upravi morao je biti dobro obrazovan, pri čemu je najcjenjenije bilo pravno obrazovanje. U Srbiji je sveučilište otvoreno 1905., pa je jasno da je među Srbima bilo mnogo manje studenata prava nego među Česima, Mađarima ili Poljacima. Hrvati su od 1874. imali Pravni fakultet koji je djelovao u sklopu Sveučilišta u Zagrebu, ali je broj zagrebačkih studenata ipak bio mnogo manji nego u drugim zemljama Monarhije. U pet akademskih godina, tj. od 1889./1890. do 1893./1894., zagrebački Pravni fakultet imao je od 170 do 248 upisanih redovnih studenata. ${ }^{15} \mathrm{U}$ tom razdoblju u Lavovu u Galiciji (1893./1894.) Pravni fakultet upisalo je 813 studenata. ${ }^{16}$ Ako dodamo studente prava na Sveučilištu u Krakovu, ${ }^{17}$ vidimo kolika je bila brojčana prednost samo Poljaka u Monarhiji nad Hrvatima. Pritom među potencijalne kandidate za posao u upravi Bosne i Hercegovine treba dodati i ostale narode Monarhije poput Čeha, Mađara i dr. Nigdje u dokumentima nema neposrednoga dokaza da Srbi i Hrvati nisu mogli dobiti visoko činovničko mjesto. Upravo suprotno, zabilježeno je nekoliko šefova sekcije ili Hofrata koji su bili Južni Slaveni (npr. Theodor P. Zurunić1 ${ }^{18}$, Emil Mraović-Grčki ${ }^{19}$ ). No ponekad su religija i podrijetlo bili kriteriji za isključenje. Godine 1914. Theodor Zurunić bio je kandidat za zamjenika zemaljskoga poglavara, ali je njegova konfesija bila prepreka: „Der gegenwärtige Vorstand der I. Abteilung der Landesregierung, Sektionschef Zurunić, würde dieser Voraussetzung entsprechen. Er ist sehr intelligent, sehr tatkräftig, arbeitsfreudig und leistungsfähig, trotzdem kann er für den Posten des Landeschefstellvertreteraus dem Grunde unmöglich in Aussicht genommen werden, weil er der serbischorthodoxen Konfession angehört und weil seine Ernennung zum Landeschefstellvertreter die Kroaten und Moslems - also gerade jene Elemente, aufdie wir uns unter allen Umständen stützen müssen - zu direkten aktiven Gegnernder Landesverwaltung machen würde", ${ }^{20}$ pisao je Oskar Potiorek.

\footnotetext{
14 DŽAJA, Bosna i Hercegovina u austrougarskom razdoblju, 110-112.

15 Spomenica o 25. godišnjici postojanja Sveučilišta Franje Josipa I. u Zagrebu, 140; ŠIDAK, Spomenica u povodu proslave 300-godišnjice Sveučilišta u Zagrebu, 242.

16 STARZYŃSKI, Historya Uniwersytetu Lwowskiego 1869-1894, 405.

17 U Lavovu i Krakovu studenti pravnoga fakulteta bili su najbrojniji, a njihov je broj svake godine rastao. DYBIEC, „Galicja na drodze do wielkiej przemiany”, 34.

18 Bošnjak. Zvanični kalendar za prostu godinu 1914, 61.

19 Bošnjak. Kalendar za prostu godinu 1902, 2.

20 JUZBAŠIĆ, ŠEHIĆ, Lične zabilješke generala Oskara Potioreka, 505.
} 
Ipak, moramo kazati da su „na papiru” svi imali jednake šanse. Zakon je bio isti za sve. Ako se poslužimo komparativnom metodom, uočavamo da je slična situacija bila krajem XVIII. i početkom XIX. stoljeća u Poljskoj, kada je ona bila podijeljena između Rusije, Austrije i Pruske. Tako su u tada austrijsku pokrajinu u nedostatku kvalificiranih službenika Poljaka na ta mjesta došli mnogobrojni Česi i u manjoj mjeri Mađari i Austrijanci. Njihova imigracija bila je uvjetovana boljim obrazovanjem i temeljitim poznavanjem njemačkoga jezika, koji je do šezdesetih godina XIX. stoljeća bio službeni jezik uprave u Galiciji. ${ }^{21}$ Istu situaciju zatječemo poslije u Bosni i Hercegovini, gdje su Hrvati, Srbi ili muslimani uzimani u državnu službu ako su imali stručne kvalifikacije. Uočavamo da su se na početku okupacijskoga razdoblja mnogobrojni Hrvati doselili u Bosnu i Hercegovinu. ${ }^{22}$ Istovremeno su učitelji u osnovnim školama čitavo vrijeme monarhijske vladavine većinom bili Srbi iz današnje Vojvodine, koji su ondje bili zaposleni na temelju svojih obrazovnih kvalifikacija, ${ }^{23}$ iako je Vlada uvijek sumnjala u njihovu političku lojalnost. Ilustrativan je primjer koji nam donosi jedan službeni Vladin dokument iz 1913. godine: ondje se uočava da je većina mladih sudskih činovnika koji su čekali promociju bila sastavljena od domaćih ljudi koji su diplomirali na Pravnom fakultetu u Beču ili na nekom drugom sveučilištu u Monarhiji. ${ }^{24}$

Naravno, politička lojalnost bila je de facto uvjet promocije pojedinaca u Zemaljskoj vladi u Sarajevu na mjesta službenika najvišega razreda, tj. VI. ili V. rangeklasse, posebno ako su zauzimali upravno mjesto Sektionschef. U tom slučaju bila je nužna kombinacija stručnih kvaliteta i odanosti Vladi, što je značilo osudu svih protudržavnih i protumonarhijskih tendencija. Nakon 1889. u Beču je sazrelo mišljenje da se takvi kadrovi mogu naći samo među strancima, odnosno u slučaju Hrvata među članovima uglednih i lojalnih plemićkih obitelji. ${ }^{25}$

Radi formiranja nove elite na koju bi se mogla osloniti, Zemaljska vlada omogućila je stipendije studentima iz Bosne i Hercegovine za studije na sveučilištima ne samo Austro-Ugarske, nego i drugih zemalja poput Njemačke, Grčke $^{26}$, pa čak i Srbije ${ }^{27}$. Uvjet za dobivanje stipendije bila je obveza da stipen-

\footnotetext{
21 RÖSKAU-RYDEL, Niemiecko-austriackie rodziny urzędnicze w Galicji 1772-1918, 66-69; BUJAK, Galicya, 178-179.

22 GROSS, „Hrvatska politika u Bosni i Hercegovini od 1878 do 1914”, 13; ĐAKOVIĆ, Političke organizacije bosanskohercegovačkih katolika Hrvata, 147-148.

${ }_{23}$ KALUĐERČIĆ, „Srbi i Srpkinje iz Vojvodine učitelji i učiteljice u Bosni i Hercegovini”, 193209.

$24 \quad$ ABH, ZVS, 1913., sign. 388, br. 11.

25 JUŽBAŠIĆ, ŠEHIĆ, Lične zabilješke generala Oskara Potioreka, 506.

$26 \mathrm{ABH}, \mathrm{ZVS}, 1901$., sign. 51, br. $3 / 3$.

$27 \quad \mathrm{ABH}, \mathrm{ZVS}, 1901$. , sign. 58, br. 78.
} 
dist nakon uspješno završenog studija radi u javnoj upravi. ${ }^{28} \mathrm{Da}$ su stipendisti bili važan državni projekt potvrđuje činjenica da im je Kállay za studij na Bečkom sveučilištu osnovao zavod. ${ }^{29}$ Pritom je pokazana posvemašnja vjerska tolerancija, pa su stipendisti muslimani i židovi imali osigurana molitvena mjesta te prehranu u skladu s vjerskim pravilima (npr. bez svinjetine). ${ }^{30} \mathrm{Iz}$ rečenog se vidi kako je Zemaljska vlada korak po korak od darovitih domaćih ljudi gradila vjernu činovničku klasu, pri čemu im nije podilazila u pitanju potrebnih kvalifikacija koje je od njih očekivala.

Ipak, stvaranje domaće činovničke elite bio je dugotrajan proces te vidimo da se Kállay početnih godina svoje uprave u Bosni i Hercegovini morao pretežno oslanjati na strane useljene službenike. Kállay je svoj stav o tome kakav treba biti modus operandi javne uprave već na početku mandata ministra zajedničkoga Ministarstva financija izrazio u memorandumu, naglašavajući da se uspjeh može postići „ne apsolutnom izvrsnošću zakona i institucija, nego samo uviđavnošću, taktom i energijom činovnika od najviših do najnižih"31. Njegovi najbliži suradnici bili su ljudi kojima se okružio još u Beogradu, kada je ondje bio generalni konzul Austro-Ugarske u Srbiji. U tom kontekstu, a u skladu s onim što sam o kadrovskoj politici Monarhije prema činovništvu u Bosni i Hercegovini prethodno kazao, valja uočiti da je položaj civilnoga adlatusa zauzeo Srbin Fedor Nikolić, koji je u novoj sredini postao omražen, pa je uskoro otišao iz Bosne i Hercegovine. ${ }^{32}$ Uzevši u obzir mnogobrojno plemstvo, građanstvo i činovništvo Monarhije, kadrovski problem Kállayu nisu bili osobni savjetnici, nego pronalazak velikoga broja službenika nužnih za javnu upravu. Što se tiče zakona o službenicima, njihov status nije bio uređen. Stoga je Kállay kao primarni zadatak odredio organizaciju javne uprave.

Prije „Kállayeve ere” život službenika u Bosni i Hercegovini nije bio lagodan ni ugodan. Mlade ljude privlačila je dobra plaća i mogućnost brzoga napredovanja u struci, međutim mnogi su od njih nakon dolaska tvrdili da je život na Balkanu težak, a skupoća sveprisutna. ${ }^{33}$ Nije u pitanju bila samo skupoća hrane, nego i problem smještaja. U gradovima je vladala stambena kriza, a k tome je infrastrukturna opremljenost bila loša, pa su manji gradovi redovito bili bez pločnika i suvremenih cesta. Izvan gradova prometne komunikacije bile su otežane jer je u prvim godinama okupacije željeznička

\footnotetext{
$28 \quad$ ABH, ZVS, 1900., sign. 58, br. 41/79.

29 PAUL, Bericht über die Tätigkeit des Institutes für bosnisch-hercegowinische Hochschüler in Wien; ABH, ZVS, 1900., sign. 58, br. 1/8.

$30 \quad$ ABH, ZVS, 1900., sign. 58, br. 1/8.

31 KRALJAČIĆ, Kalajev režim u Bosni i Hercegovini, 437.

32 MNK, sign. 1614/1882.

33 „Stosunki w Bośni”, Urzędnik (Przemyśl), 1880., br. 2, 11.
} 
mreža bila tek u povojima. Sve su to bili glavni praktični problemi s kojima se u koštac trebao uhvatiti prosječni službenik nižega razreda, manipulativni činovnik ili dnevničar. ${ }^{34}$

Mnogi austrougarski službenici koji su dolazili u Bosnu i Hercegovinu često su poslije napuštali zemlju i tražili sreću na drugim mjestima. Kako su ti pripadnici slobodnih zanimanja često putovali sa svojim kovčezima, stranci su u Bosni i Hercegovini, a među njima posebno Nijemci i Mađari, prozvani „kuferašima” 35 . Frustriranost životom na periferiji Carstva neke od njih natjerala je na napuštanje pokrajine usprkos napredovanju u karijeri. Ništa to ne ilustrira bolje od slučaja Jarosława Stebelskog, koji je od 1907. bio potpredsjednik Vrhovnoga suda u Krakovu. ${ }^{36}$ On je kao mlad čovjek započeo karijeru 1880-ih u Zvorniku, gradu u kojem je dobio počasno građanstvo; ipak je poslije odlučio napustiti Balkanski poluotok, a galicijskom tisku to je objasnio riječima da „uvjeti u toj zemlji ne odgovaraju civiliziranom čovjeku”"

Benjamin von Kállay bio je odgovoran za reformu pravnoga statusa službenika. Naime, do 1886. strani činovnici radili su prije svega u vlastitoj zemlji u Monarhiji (npr. u Češkoj, Galiciji, Moravskoj), a na službu u Bosnu i Hercegovinu dolazili su kratkotrajno i po ispunjenju misije vraćali su se u zemlju podrijetla. ${ }^{38} \mathrm{U}$ takvim uvjetima nisu se posve angažirali na službi u Bosni i Hercegovini, tim više što ondje nije bilo sređeno radno zakonodavstvo; pritom se kao veliki problem pokazala činjenica da ondje nije postojao regulirani mirovinski status službenika. Pod Kállayem su donesene uredbe u korist činovnika: zakonom iz $1885 .{ }^{39}$ zajamčene su mirovine službenicima, a drugim iz $1886 .{ }^{40}$ formiran je poseban socijalni fond u Unionbanku za isplatu činovničkih mirovina. To je stvorilo preduvjete da činovnik može dobiti mirovinu nakon četrdeset godina rada ili prije u slučaju bolesti, za što je pak trebao jamčiti liječnički nalaz. Tom reformom Kállay je osnažio javnu upravu, koja je do tada imala više privremeni nego stalni karakter.

Činovnički položaj ovisio je i o drugim čimbenicima na koje je vlast morala obratiti pozornost i približiti kvalitetu života u Bosni i Hercegovini drugim zemljama Monarhije. To se najviše osjetilo u svakodnevici, u koju je Monarhija

\footnotetext{
34 „Z powodu emigracyi do Bośni”, Urzędnik, 1880., br. 14, 109.

35 HADŽIBEGOVIĆ, Bosanskohercegovački gradovi na razmeđu 19. i 20. stoljeća, 52.

36 CZECH, Kalendarz krakowski na rok 1907, 111.

37 „Rozmaitości”, Urzędnik, 1880., br. 12, 95.

38 KRALJAČIĆ, Kalajev režim u Bosni i Hercegovini, 437; SCHMID, Bosnien und die Herzegovina unter der Verwaltung Österreich-Ungarns, 60.

39 Glasnik zakona i naredaba za Bosnu i Hercegovinu, 1885., 533-552; SCHMID, Bosnien und die Herzegovina unter der Verwaltung Österreich-Ungarns, 61-62.

40 Glasnik zakona i naredaba za Bosnu i Hercegovinu, 1886., 50-51.
} 
intervenirala gradnjom cesta, stanova itd. Osim toga Vlada je tražila način da omogući napredovanje mladim službenicima koji su težili višim položajima. Sve to činilo se da bi u Bosnu i Hercegovinu dolazilo više sveučilišno obrazovanih pojedinaca, dakle stručnjaka, odanih Zemaljskoj vladi, a s druge strane stjecali su poštovanje ljudi u novoj sredini zbog prijemčivosti i poštenja.

\section{Službenički ispiti}

Neovisno o tome gdje je mlad čovjek želio raditi, morao je polagati službenički ispit, kojim su se provjeravala njegova teorijska i praktična znanja. Da bi pristupio ispitu, morao je poslati molbu Zemaljskoj vladi da se za nj organizira stručni ispit. Ako je već radio kao Vladin službenik te je želio dobiti viši položaj, trebao je samo predati pismo s molbom za ispit. Ako već nije bio dnevničar ili na praksi u uredu, tada je morao priložiti potvrdu „moralne kvalifikacije”. ${ }^{41}$ Spomenuta potvrda bila je osobito važna u slučaju prijava za učiteljska mjesta ${ }^{42}$ jer je u njihovim rukama bila budućnost novih generacija. Pojedinac koji bi podnio molbu morao je priložiti dokaz da je završio praksu i to potvrditi pečatom nadređenoga. ${ }^{43}$

Ispiti su se održavali dva puta godišnje. Mjesto održavanja ovisilo je o profesiji službenika, pa je to u nekim slučajevima bio ured, a ponekad je ispit bio dogovoren na nekom drugom mjestu. Ispitna komisija imala je u pravilu tri člana, no taj broj mogao je biti i veći. ${ }^{44}$ Kada se radilo o natječaju za mjesto u financijskoj službi, jedan od članova komisije morao je biti šef računskoga odsjeka, a uz njega su bili profesor računovodstva i ispitivač kojega bi pozivala Vlada. ${ }^{45}$ U slučaju kandidata za sudski položaj provjera znanja bila je povjerena sucima Vrhovnoga suda u Sarajevu ili okružnoga suda. ${ }^{46}$ Ako je ispitu pristupao geometar, njegov ispitivač bio je geometar višega razreda. ${ }^{47}$

Komisija je nakon ispita sastavljala izvještaj, ${ }^{48}$ koji je sadržavao sve podatke o pristupniku i njegove ocjene. Ljestvica ocjena bila je od jedan do četiri, gdje su prve tri ocjene (odličan, vrlo dobar i dobar) bile prolazne, a ocjena četiri bila je nedovoljna. Kandidati koji su se željeli ponovo natjecati na ispitu za službenička mjesta morali su pravo ponovnoga pristupa ispitu čekati šest mjeseci. U

\footnotetext{
41 Glasnik zakona i naredaba za Bosnu i Hercegovinu, 1891., 100.

42 Glasnik zakona i naredaba za Bosnu i Hercegovinu, 1904., 193.

43 Glasnik zakona i naredaba za Bosnu i Hercegovinu, 1902., 21.

44 Glasnik zakona i naredaba za Bosnu i Hercegovinu, 1891., 101.

45 Isto.

46 Glasnik zakona i naredaba za Bosnu i Hercegovinu, 1902., 20.

47 Glasnik zakona i naredaba za Bosnu i Hercegovinu, 1907., 695.

$48 \mathrm{ABH}, \mathrm{ZVS}, 1911$., sign. 10, br. 5/10.
} 
slučaju financijskih službenika komisija je morala dati odobrenje za ponovno pristupanje ispitu za šest mjeseci ili godinu dana. ${ }^{49}$ Kandidati koji dva puta ne bi zadovoljili na ispitu morali su kao uvjet za daljnje pokušaje polaganja ispita upisati tečaj, po čijem su uspješnom završetku ponovno dobivali pravo pristupa ispitu. ${ }^{50}$

U slučaju kandidata za službenika financijskoga računovodstva ispit je uključivao provjeru znanja računovodstva i austrougarskoga upravno-političkog sustava. Iako je komisija u Sarajevu bila nadležna za sve računovodstvene ispite u Bosni i Hercegovini, postojala je mogućnost da kandidati budu oslobođeni pristupanja ispitu ako su prethodno u nekoj od zemalja Monarhije položili sličan ispit jer je rezultat takva ispita uživao isti pravni status kao ispit položen u Bosni i Hercegovini. ${ }^{51}$ Ako nije imao položen ispit u drugoj zemlji Monarhije, kandidat je morao pred komisijom u Sarajevu polagati pismeni i usmeni ispit. ${ }^{52}$

Ispiti su trajali više sati. Najprije bi se održavao pismeni ispit, koji je trajao od 8 do 18 sati. ${ }^{53}$ Usmeni ispit trajao je između jednoga i dva sata. ${ }^{54}$ Ispiti su pokrivali različita područja: sudstvo, organizaciju uprave u općinama, rudarstvo, šumarstvo itd. Sve je bilo zastupljeno s nekoliko pitanja. ${ }^{55}$ Važno je napomenuti da je budući službenik morao dokazati poznavanje upravnoga prava, ali i računovodstva. ${ }^{56}$ Najteži ispit polagali su geometri. Njihov ispit sastojao se od teorijskoga dijela, koji se dijelio na pismeni i usmeni i tražio je poznavanje zakona te matematike i fizike, i praktičnoga dijela, u kojem je kandidat na terenu morao provesti mjerenja, crtati karte i na osnovi toga sastaviti katastarske podatke, popis zgrada, polja itd. ${ }^{57}$

Nakon što bi budući službenik položio ispit morao je napisati pismo da bi ga Vlada prihvatila. U tom pismu morao je navesti podatke o rođenju, obrazovanju, radnom iskustvu, položenim ispitima i vojnoj službi. Kao dokaz trebao je priložiti indeks, potvrdu o položenom službeničkom ispitu, mišljenje nadređenoga koji je nadzirao njegovu praksu te dokaz o odsluženom vojnom roku. Posebno je morao priložiti liječničku potvrdu da nema zdravstvenih problema koji bi ga ometali u službi. Temeljni pravni preduvjet kandidature ipak je bilo

\footnotetext{
49 Glasnik zakona i naredaba za Bosnu i Hercegovinu, 1902., 22.

50 Glasnik zakona i naredaba za Bosnu i Hercegovinu, 1891., 101.

51 Glasnik zakona i naredaba za Bosnu i Hercegovinu, 1886., 182.

52 Glasnik zakona i naredaba za Bosnu i Hercegovinu, 1902., 21.

53 Isto.

54 Isto, 22.

55 ABH, ZVS, 1911., sign. 10, br. 5/10.

56 Isto.

57 Glasnik zakona i naredaba za Bosnu i Hercegovinu, 1907., 695.
} 
građanstvo; kandidat je morao biti državljanin Bosne i Hercegovine ili druge zemlje Austrije ili Ugarske. Molba koju je prilagao da ga se prihvati na posao bila je pisana na njemačkom ili zemaljskom jeziku. ${ }^{58}$ Ista procedura vrijedila je za cijelu Monarhiju, pa i za Bosnu i Hercegovinu. ${ }^{59}$

Naposljetku, prije stupanja u službu javne uprave kandidat je morao potpisati prisegu vjernosti dinastiji, odnosno da će biti dobar i vjeran službenik Franje Josipa I., a poslije Karla I. Ako je prisegu davao službenik muslimanske vjeroispovijesti, potpisao bi da priseže Alahom, a katolički, pravoslavni i židovski vjernici da prisežu svojim Bogom. ${ }^{60}$

Sve spomenuto ipak je bila pravno sazdana teorija: u praksi su za buduće službenike važniji čimbenik pri zapošljavanju od ispita, radnoga iskustva i obrazovanja bile njihove društvene veze. Visokopozicionirani pojedinci mogli su svojim štićenicima pomoći u postavljanju u javnu službu. Slikovit je primjer korespondencija češkoga plemića Otta von Harracha, koja se čuva u Haus, Hof- und Staatsarchivu u Beču, gdje se nalazi nekoliko pisama nekih čeških službenika koji su molili kneza neka im pomogne da dobiju posao u Bosni i Hercegovini ili pri unapređenju. ${ }^{61}$

Slične molbe nalazimo i u pismima Leonu Bilińskom iz vremena kada je bio zajednički ministar financija. Tako je 1912., nakon što je postao ministar, dobio molbu Teofila Maciejowskog, Rusina koji ga je molio neka postavi njegova rođaka Józefa Hlebowickog na mjesto nadzornika tvornice duhana u Banjoj Luci. Kao ilustraciju prilika koje su vladale pri postavljanju činovnika donosimo isječak pisma: „[...] najłaskawiej raczył w swej dobroci i z poczucia sprawiedliwości zwrócić swą uwagę na podanie pana Józefa Hlebowickiego, który opuścił swą ojczyznę z bólem serca by szukać chleba na obczyźnie i w razie dobrej kwalifikacyi najłaskawiej zamianować go Dyrektorem fabryki tytoniu w Banja Luce w Bośni."'62 Usprkos pismu, Hlebowicki nije dobio taj posao, no zabilježen je 1915. kao tajnik tvornice duhana u Sarajevu. ${ }^{63}$

\footnotetext{
$58 \quad \mathrm{ABH}, \mathrm{ZVS}, 1910$., sign. 10, br. 4/19.

59 HHSA, Kab.-Archiv, sign. 58-909/1909-1911.

60 Glasnik zakona i naredaba za Bosnu i Hercegovinu, 1907., 182-183; ABH, ZVS, 1904., sign. 5, br. $6 / 2$ i br. $6 / 3$.

61 HHSA, Otto von Harrach, sign. 866.

62 „[...] znajući Vašu dobrotu i pravičnost, najljubaznije Vam skrećem pažnju na pismo [molbu] gospodina Józefa Hlebowickog, koji je napustio svoju domovinu te uz veliku nostalgiju došao u stranu zemlju kako bi našao kruha, stoga ako Vam se njegove kvalifikacije čine odgovarajućim, molim da ga zaposlite kao ravnatelja tvornice duhana u Banjoj Luci u Bosni.” ABH, Gabinet Briefe, sign. 978/1912.

63 Bosanskiglasnik (Sarajevo), 1915., 120.
} 
Takva praksa, kao što se vidi, nije bila rijetkost. Nije to bio problem samo Bosne i Hercegovine, nego čitave Monarhije; nepotizam je bio svakodnevna bolest koja je pratila činovništvo od nižega do višega razreda. To ističem jer je komparativnom metodom ustanovljeno slično stanje i u drugim zemljama Monarhije, poput Galicije, Češke, pa i same Austrije, iz čega se vidi da je problem nepotizma postojao za cijeloga razdoblja Austro-Ugarske Monarhije. ${ }^{64}$

\section{Stranac u bosanskohercegovačkoj upravi}

Nakon što bi kandidat uspješno položio sve ispite, mogao je kao činovnik prionuti svojem novom poslu. Službenik koji je imao prethodno radno iskustvo u perspektivi je bio potencijalno bolji radnik te je time osiguravao prednost pred novacima. Valja napomenuti da su Poljaci, Česi, Mađari i drugi smatrali Bosnu i Hercegovinu egzotičnom zemljom zbog njezina islamskoga nasljeđa. Kako u svojim zemljama nisu imali prilike upoznati muslimansku kulturu i religiju, morali su se naviknuti na nove okolnosti. Po dolasku u Bosnu i Hercegovinu mnogi službenici smatrali su se nekim iznimnim pojavama. Naravno, službeni radni stol, mastionica te naramenice na službenom odijelu bili su san mnogih momaka. Ipak, u orijentalnoj klimi, Vlada koja je davala poslove imala je nešto drugačiji ukus za veličinu od mladih kandidata. Suvremena periodika donosila je podatke o novozaposlenim činovnicima; tako su u Sarajevskom listu i Bosanskohercegovačkim novinama na naslovnici izlazile informacije o novim činovnicima i promocijama postojećih službenika. ${ }^{65}$

U IX. rang (bilo ih je dvanaest) činovnika je imenovao zemaljski poglavar ili njegov zastupnik, u VIII. i VII. zajednički ministar financija, a od VI. do I. ranga isključivo osobno car na zahtjev šefa ministarstva u kojem je službenik radio. ${ }^{66}$ Tek nakon toga službenik je postajao punopravni zaposlenik javne uprave.

Početak službe u Bosni i Hercegovini često je bio obilježen domjenkom koji su organizirali budući kolege činovnici, ili lokalna elita ako je novi činovnik dolazio na službu u mali grad. Na taj način prihvaćali su nove kolege. Zahvaljujući tome službenik je mogao poimenično upoznati sve pismene osobe u novoj sredini jer je u malim gradovima pismenost najčešće bila ograničena samo na službenike javne uprave, njihove supruge i židovske rabine, musli-

64 HEINDL, Josephinische Mandarine, 172.

65 Rubrika „Zvanično” u Bosanskohercegovačkim novinama za godine 1878. - 1880. i ista rubrika u Sarajevskom listu 1881. - 1884.

${ }^{66}$ SLADOVIĆ SLADOEVIČKI, Upravna nauka i upravno pravo Bosne i Hercegovine, 46. 
mansku ulemu i katoličko i pravoslavno svećenstvo, ovisno o vjerskoj slici. ${ }^{67} \mathrm{Za}$ mlade ljude koji su odlučili napustiti svoju zemlju i doći u Bosnu i Hercegovinu stjecanje dobra prijatelja bio je jako važan faktor. Zemaljska uprava bila je, kao uostalom i Monarhija, mozaik nacija, gdje su radili ljudi različitih vjera i jezika. Poljski službenik Teodor Kasparek pisao je o činovništvu u Bosni i Hercegovini uspoređujući ga s babilonskom kulom: „Kto pragnie poznać zbliska typy narodowościowe, składające się na mozaikę austro-węgierską, potrzebuje tylko wstąpić na parę lat do bośniackiej służby. Istna wieża Babel języków, poglądów, upodobań, skłonności, zwyczajów i obyczajów!"68

Dobro društvo bilo je potrebno ne samo na poslu, nego i u svakodnevnom životu, osobito mladim ljudima na početku boravka u Bosni i Hercegovini. Mladi službenici isprva su radili pod nadzorom starijega kolege kao mentora. Javna uprava ustrojena na hijerarhijskoj osnovi stvarala je određenu jednoličnost premda su se ondje nalazili ljudi koji su se razlikovali po vjeri, jeziku i nacionalnosti, čak i ako su imali prijatelje iz drugih gradskih zanimanja i skupina. Većina službenika družila se s ostalim službenicima. Ta prijateljstva bila su osnova za druženje, bračno povezivanje s kćerima ili sestrama drugih službenika, ali i društvena sigurnosna niša jer su službenici nastupajući kao de facto društveni stalež gajili međusobnu solidarnost, pa su u slučaju grešaka na poslu kolege čuvali njihov obraz u očima javnosti jer je on bio simbol vlasti. ${ }^{69}$

Osjećaj da su članovi javne uprave pripadnici zasebne društvene zajednice imao je korijene ne samo u društvenom elitizmu proisteklom iz obrazovanja, nego prije svega u privilegijima koje su uživali. Kako bi pokrenuo migraciju mladih službenika iz drugih zemalja Monarhije, Benjamin von Kállay dao im je povlastice koje nisu imali u svojoj zemlji. Ako usporedimo položaj službenika u Bosni i Hercegovini s onim u Galiciji, uočavamo da su na Balkanu bili bolji radni uvjeti i veća mogućnost za brzo napredovanje u karijeri! ${ }^{70}$

Moram ovdje odgovoriti na još jedno važno pitanje - zašto su uopće službenici iz Galicije u većem broju odlazili u Bosnu i Hercegovinu? Najvažniji

\footnotetext{
67 Kada je Austrija došla u Bosnu i Hercegovinu, bilo je nepismeno 97 \% ljudi, a u provinciji je pismena bila samo lokalna elita, osobito vjerska. PAPIĆ, Školstvo u Bosni i Hercegovini za vrijeme austrougarske okupacije, 7 .

68 „Tko želi osobno upoznati sve raznolike nacije koje su dio austrougarskoga mozaika, treba se zaposliti nekoliko godina u bosanskoj upravi. To je stvarna babilonska kula jezika, mišljenja, zanimanja, sklonosti i običaja." KASPAREK, Bośnia a emigracya galicyjska, 30.

69 PFEFFER, Istraga u sarajevskom atentatu, 9-10.

70 O tome je pisao galicijski tisak, u kojem su uspoređeni troškovi službenika u Bosni i Hercegovini s onima u Galiciji. „Wiadomości potoczne”, Reforma Urzędnicza (Lwów), 1912., br. 11, 6; „Wiadomości otoczne”, Reforma Urzędnicza, 1913., br. 11, 3. Isusovac Marcin Czermiński u svojem je putopisu tvrdio da poljski službenici bolje žive u Bosni i Hercegovini nego u Galiciji. CZERMIŃSKI, Z podróży po Bośni i Hercegowinie, 58.
} 
su razlog društvene prilike u Galiciji. Bosanskohercegovačka Zemaljska vlada pružala je više mogućnosti mladim činovnicima nego upravni poslovi u rodnom kraju, tim više što je Galicija bila siromašna zemlja, koja nije mogla zaposliti toliki broj mladih koji su svake godine završavali pravni fakultet. ${ }^{71}$ Osim toga, za najbolja mjesta u upravi u pravilu su bili predodređeni sinovi elite, što je mnogim mladićima iz seljačkih obitelji zatvaralo put do karijere. Važnost podrijetla za uspjeh u karijeri vidi se na primjeru Galicije, gdje je od 164 poljskih službenika višega razreda (VIII. ranga) tek njih 32 potjecalo iz seljačkih ili radničkih obitelji. ${ }^{72}$ Zbog specifične situacije javna služba bila je otvorenija prema mladim ljudima u Bosni i Hercegovini nego u drugim zemljama Austro-Ugarske. Ondje nije bilo baš toliko važno obiteljsko podrijetlo koliko radno iskustvo i obrazovanje pojedinca.

Takve okolnosti potaknule su dolazak i uključivanje mnogih Židova Aškenaza iz cijele Monarhije u upravu Bosne i Hercegovine jer su bili obrazovani na raznim sveučilištima Austro-Ugarske. ${ }^{73}$ Njihove migracije treba gledati i u kontekstu antisemitizma koji je postojao u Monarhiji, a može se vidjeti i u slučaju Galicije. ${ }^{74}$ Nasuprot tome, javna uprava Bosne i Hercegovine bila je kao „babilonska kula”, gdje su zajedno radili ljudi različitih jezika, vjera i kulture koji su u očima Vlade svi bili jednaki i imali iste zadatke: služiti i raditi bez pogovora.

U praksi su u javnoj upravi postojale profesije u kojima su dominirale pojedine nacije. Tako se uočava da su među sucima većinu službenika činili Poljaci iz Galicije, a u slučaju inženjera i arhitekata najzastupljeniji su bili Česi. ${ }^{75}$ Naravno, bilo je iznimaka, poput dugogodišnjega suca Vrhovnoga suda Friedricha Kobingera, koji je po nacionalnosti bio Čeh, ${ }^{76}$ a Poljak Robert Miączyński kao geometar bio je po obrazovanju inženjer ${ }^{77}$.

\footnotetext{
71 BANACH, Kariery zawodowe studentów Uniwersytetu Jagiellońskiego pochodzenia chłopskiego, 88 .

72 Ovo su podaci iz Arhiva $\mathrm{BiH}$, iz fonda Zemaljska vlada za Sarajevo, koje sam našao za godine 1879. - 1918., a i iz drugih izvora (npr. kalendar Bošnjak ili Bosanski glasnik). Osim toga pripremao sam popis Poljaka višega razreda koji će se naći u knjizi koju namjeravam objaviti.

73 TAUBER, Jevrejska štampa u BiH 1900-2011, 14-15; PINTO, Jevreji Sarajeva i Bosne i Hercegovine, 13-17; JUZBAŠIĆ, Politika i privreda u Bosni i Hercegovini pod austrougarskom upravom, 371-374.

74 SOBOŃ, Polacy wobec Żydów w Galicji, 221-284.

75 KRZYK, Česi u Sarajevu 1878-2010, 127-133; PULJIĆ, ŠETKA PRLJIĆ, RAKIĆ, „Arhitekti i graditelji u Mostaru za vrijeme Austro-Ugarske Monarhije”, 2-19.

76 „Preminuo Friedrich Kobinger”, Narodno jedinstvo (Sarajevo), 7. 11. 1919., 2.

$77 \mathrm{ABH}, \mathrm{PD}$, Robert Miaczynski.
} 
Broj Poljaka, pripadnika višega službeničkog razreda, koji su radili na okružnim sudovima u Bosni i Hercegovini (1886. - 1916.) ${ }^{78}$

\begin{tabular}{|l|c|c|c|c|c|c|c|}
\hline Godina & Banja Luka & Bihać & Mostar & Sarajevo & Travnik & Tuzla & Ukupno \\
\hline 1886. & 0 & 1 & 1 & 2 & 1 & 4 & 9 \\
\hline 1891. & 1 & 4 & 2 & 0 & 4 & 3 & 14 \\
\hline 1896. & 5 & 3 & 1 & 2 & 5 & 5 & 21 \\
\hline 1901. & 3 & 4 & 3 & 4 & 5 & 4 & 23 \\
\hline 1906. & 4 & 3 & 4 & 5 & 4 & 5 & 25 \\
\hline 1911. & 4 & 6 & 3 & 6 & 4 & 5 & 28 \\
\hline 1916. & 6 & 0 & 2 & 4 & 5 & 5 & 22 \\
\hline
\end{tabular}

Promjena mjesta službovanja

Ako se službenik želio preseliti u drugo mjesto zbog posla ${ }^{79}$ ili osobnih razloga ${ }^{80}$, morao je napisati posebno pismo svojem uredu i u njemu objasniti zašto se odlučio na selidbu, kamo želi otići i, što je bilo vrlo važno, tko će ga zamijeniti. ${ }^{81}$ Razlozi su bili različiti: želja da žive uz obitelj, bolje financijske mogućnosti, a ponekad su tvrdili da im ne odgovara klima. ${ }^{82}$ Taj se razlog, iako mi se ne čini uistinu važan, često koristio. Tomasz Nedej Mikołajewicz tvrdio je da zbog klime mora napustiti upravu u Banjoj Luci i vratiti se u Lavov. ${ }^{83}$ Ponekad su motivi bili isključivo ekonomske prirode. To nam potvrđuje slučaj Stjepana Markova, koji je molio Vladu neka ga ostavi u Banjoj Luci, gdje je radio u zatvoru, jer je ondje kupio dvije krave, čije mlijeko prodaje kolegama službenicima. Osim toga izjavio je da njegova žena u Banjoj Luci ima obitelj od koje se ne želi udaljavati. ${ }^{84}$

Razlozi za premještaj bili su različiti. Uvijek se mogao dobiti premještaj u Banju Luku, Mostar ili Sarajevo, a još je lakše Vlada odobravala molbe za premještaj u manje gradove blizu granice s Turskom, „gdje su modernizacijski procesi još bili u najboljem slučaju u povojima”. ${ }^{55}$ Sve je ovisilo o mišljenju činovničkoga poglavara. Kako sam spomenuo, hijerarhijska priroda uprave dovela je do toga da je za sve odluke, pa tako i ove, najvažniji bio naređeni, koji

\footnotetext{
78 Statistika na osnovi izvještaja kalendara Bošnjak za godine 1886. - 1898. i Bosanskoga glasnika 1899. - 1918.

79 ABH, ZVS, 1901., sign. 107, br. 966/4.

$80 \quad \mathrm{ABH}, \mathrm{ZVS}, 1900$., sign. 107, br. 629.

$81 \quad \mathrm{ABH}, \mathrm{ZVS}, 1900$., sign. 107, br. 635.

82 ABH, ZVS, 1912., sign. 388, br. 1095/3.

83 ABH, ZVS, 1900., sign. 107, br. 629.

84 ABH, ZVS, 1901., sign. 107, br. 86/3.

85 BJ, Rkps, fond Adama Ferensa, Na fali wspomnień, sign. 45/68.
} 
je sa svojim osobljem mogao raditi sve što je želio. ${ }^{86} \mathrm{Zbog}$ toga su u praksi neki premještaji službenicima bili nagrada odnosno kazna nadređenih.

Kada se pogledaju radna mjesta službenika, uočava se da se naziv „kuferaši” ne odnosi na sve službenike, nego samo na one mlade, koji su tek započeli karijeru ili su bili činovnici bez obrazovanja. Ako usporedimo sve tri radne skupine: činovnike Zemaljske vlade, liječnike i suce, moramo primijetiti da je njihova mobilnost bila različitoga intenziteta i znatno ovisila o prirodi i opsegu posla.

Najmanje su svoje mjesto mijenjali službenici Zemaljske vlade. Oni koji su se zaposlili na prijelazu stoljeća, radili su u sarajevskoj upravi prosječno devetnaest godina. Ipak, taj prosjek u stvarnosti su znali znatno remetiti slučajevi drugih službenika, koji su ostajali i duže: pogledaju li se pojedinačne karijere službenika, uočavamo da je većina radila u Sarajevu više od dvadeset, a neki od njih i po trideset godina! Teško je reći da su te osobe bile „kuferaši”.

Slična je situacija bila što se tiče liječnika. I među njima je bilo onih koji su radili u jednom gradu više od dvadeset godina, ${ }^{87}$ pa su tako zapravo u Bosni i Hercegovini radili cijeli život, vjenčali se, školovali djecu u lokalnim školama itd. Takvi pojedinci postali su neraskidivo i nepobitno povezani s novom zemljom, što nam svjedoče primjeri Ladislaua Januszewskog, koji je radio u Banjoj Luci od 1882. do 1910., ili Bogusławą Keckova, koji je u Tuzli radio od 1893. do 1911. godine. ${ }^{88}$ Mogu se pronaći i drugačiji primjeri, poput liječnika koji su kratkotrajno dolazili u Bosnu i Hercegovinu, u prvom redu da zarade nešto više novca, i vratili se kući. Njihov bi boravak trajao kratko, samo nekoliko mjeseci, ponekad godinu ili dvije. Posebno mjesto među liječnicima zauzimali su vojni liječnici ${ }^{99}$ (posebno na početku okupacije) i mladi liječnici koji su dolazili u Bosnu i Hercegovinu steći iskustvo i preporuku nadređenih za povratak u svoju zemlju, gdje su kanili graditi dugoročnu liječničku karijeru.

\footnotetext{
86 KASPAREK, Bośnia a emigracya galicyjska, 31.

${ }_{87}$ Ako pogledamo karijere službenika višega razreda, npr. Emila Woske, njemačkoga činovnika rođenog u Češkoj koji je više od dvadeset godina služio u Sarajevu, ili Karola Stefanowskog, činovnika Zemaljske vlade koji je u Bosni i Hercegovini radio od 1879. do Prvoga svjetskog rata, nikako se ne može reći da su oni bili „kuferaši” jer su više godina živjeli u jednom gradu. ABH, PD, Emil Woska [ne postoji inventarni broj]; ABH, PD, Karol Stefanowski [ne postoji inventarni broj].

88 TAHIROVIĆ, FUCHS, „Bogusławą Keckova”, 232-249.

89 Na taj način u Bosnu i Hercegovinu došlo je mnogo liječnika. Neki su ostali (Leopold Glück, Bernard Zauderer), a neki su se vratili, kao Leon Barański, koji je poslije bio profesor na Medicinskom fakultetu Jagelonskoga sveučilišta. Kronika Uniwersytetu Jagiellońskiego od 1884 do 1887 roku, 59.
} 
Među njima su najčešće bili Austrijanci, ali i Poljaci, najprije iz Krakova, gdje je djelovao medicinski fakultet ${ }^{90}$, a od 1894. iz Lavova ${ }^{91}$.

Bosanskohercegovačka uprava oslanjala se na sudstvo. Kotarski sudovi koji su radili u kotarskim uredima, okružni sudovi i napokon Vrhovni sud bili su jamstvo vladavine prava. Među sucima se najbolje uočavaju korelacije između ranga i mobilnosti. U sudskoj hijerarhiji najniži rang bio je IX., tj. sudski pristavi, i oni su bili najmobilnija skupina među pravnim službenicima. No, kako su se službenici penjali na hijerarhijskoj ljestvici, tako je njihov položaj postajao manje mobilan i sve više teritorijaliziran. Napominjemo da ovu analizu donosimo samo za suce, ali vjerujemo da se ta tvrdnja može protegnuti na sve profesije. Stoga možemo konstatirati da se pojam „kuferaši” pretežno odnosio na mlade ljude koji su bili na početku karijere ili neobrazovane službenike bez perspektive za promociju. Mobilnost sudskih djelatnika prema rangovima može se predočiti sljedećim grafikonom.

Mobilnost poljskoga sudskog djelatnika prema rangu ${ }^{92}$

Kao što smo ustanovili, mladi činovnici koji su tek zasnivali radni odnos na sudu češće su mijenjali radno mjesto nego stariji službenici. Generalno, službenici koji su spadali u IX. rang mijenjali su radno mjesto više od tri puta, a oni od VI. ili V. ranga (trajno) ostajali na jednom mjestu kao predsjednici suda. Postavlja se pitanje zašto je to bilo tako? Ključni utjecaji dolazili su od obitelji i financijskih prilika. Prvo, većina ih kao studenti nisu zasnovali obitelj, zapravo bi se ženili tek s početkom rada u Bosni i Hercegovini. Nakon vjenčanja u Bosni i Hercegovini nisu imali problema osigurati da dijete pohađa školu itd. Druga je stvar bila financijske prirode: mladi ljudi tražili bi bilo kakav posao na kojem su mogli ostvariti veću zaradu..$^{93}$ Kao početnici u hijerarhijskom društvu imali su slab položaj, pa ako bi dobili naredbu da se moraju preseliti, u praksi se nikako tome nisu mogli protiviti. Ipak, s obzirom na to da je Austro-Ugarska bila pravna država, ako se podređeni nisu slagali s odlukom svojih naređenih o premještaju, mogli su poslati molbu, koja bi ponekad bila riješena u njihovu korist. ${ }^{94}$

\footnotetext{
$90 \quad$ ABH, ZVS, 1903., sign. 52, br. 350/2.

91 Isto.

92 Okomita crta je broj promjena mjesta rada činovnika, a vodoravna njegov rang.

93 ABH, ZVS, 1913., sign. 388, br. 1090/4.

94 BJ, Rkps, fond Adama Ferensa, Na fali wspomnień, sign. 45/68.
} 


\section{Svakodnevni život}

Važan dio života službenika u Bosni i Hercegovini bilo je njihovo slobodno vrijeme. To su vrijeme, ako su bili vjenčani, mogli provoditi sa suprugom i djecom ili su se mogli zabavljati na drugi način. Jedna od neslužbenih zabava bio je odlazak u bordel, ali učestaliji oblici bili su činovnička društva, kasina ili knjižnice te sport i turistička putovanja.

Što se tiče bordela, oni su nakon okupacije doživjeli konjunkturu, prije svega priljevom velikoga broja službenika. ${ }^{95}$ Činovnička emigracija dominantno je bila sastavljena od nekadašnjih studenata, većinom samaca. Neki su u zemljama podrijetla ostavljali supruge i kao ekonomski emigranti odlazili u Bosnu i Hercegovinu da zarade. ${ }^{96}$ Na početku okupacije demografski odnosi muškaraca i žena bili su brojčano poremećeni. ${ }^{97} \mathrm{U}$ Bosni i Hercegovini bilo je 1000 muškaraca na 895 žena. Autor, često citiranih memoara češki žandar Valoušek navodi da su žene često dolazile u Bosnu i Hercegovinu i ondje tražile supruga, a tim kretanjima pogodovala je činjenica da se službenici u početku nisu mogli oženiti muslimankama, vjerojatno zbog toga što bi to uključivalo ženinu vjersku konverziju. ${ }^{98}$ Ako ne bi pronašle supruga, ponekad bi zbog siromaštva završile na ulici ili bi se zapošljavale u bordelima. Ako pogledamo policijske popise prostitutki, uočavamo da su mnoge od njih bile djevojke iz drugih zemalja Dvojne Monarhije i radile u Bosni i Hercegovini. Proučavajući jedan takav popis, poslužio sam se onomastičkom metodom, iz čega je vidljivo da je od 14 žena samo njih 6 bilo iz Bosne i Hercegovine. ${ }^{99}$ Toliki broj stranih prostitutki najbolji je dokaz da je postojala velika potražnja za tom profesijom. Treba biti pošten i reći da usprkos tome što je prostitucija bila legalna u čitavoj Austro-Ugarskoj, ${ }^{100}$ pa tako i u Bosni i Hercegovini, korištenje usluga ponekad je bilo problem za činovnike. To se jasno vidi iz pisma koje je 1912. primila Zemaljska vlada. U njemu se kaže da u Banjoj Luci u objektu koji se službeno vodi kao hotel djeluje bordel u koji odlaze mnogi činovnici. Pismo, uz neka kraćenja, glasi:

\footnotetext{
${ }_{95}$ KASUMOVIĆ, „Prilog povijesti marginalnih skupina u Bosni i Hercegovini u doba austro-ugarske uprave: prostitutke”, 162.

96 MAGIERA, Ludność Polska w Bośni, 2.

$97 \quad$ VALOUŠEK, Sjećanja na Bosnu, 107.

98 Isto.

$99 \quad$ ABH, ZVS, 1912., sign. 21, br. 20/39.

100 BACZKOWSKI, „Prostytucja w Krakowie na przełomie XIX i XX wieku”, 593-596.
} 


\begin{abstract}
„U našoj ulici smješten je gradski kotarski ured i od nove godine pokraj ovog ureda otvorena je mehana ili po stanju stvari pravo rečeno javna kuća. Gradski kotarski ured odnosno njegovi službenici javno vide i čuju šta se u ovoj nazovi mehani zbiva šta se radi, i ko sve radi pa neće ovom zlu da stane na kraj nego šta više ovo zlo oni potpomažu. [...] vidila očevidac sam bio kad neki dan dodje Crneković nekakav činovnik kod naše općine i uze curu ispod ruke i od Mahnikovice sobu na jedan sat. Zar se može nazvati nego javna kuća bez dozvole? Ovaj isti Crneković po cijele noći provodi u ovoj zloglasnoj kući otvoreno se sa nekakvim curetinama kurva i svaka zla čini a naš gradski kotarski ured kao nad ziratelj naše općine i njezinih službenika to vidi ali neće da vidi [...] To je istinita ali žalosna i najžalosnija slika za našu upravu."101
\end{abstract}

Službenik Teodor Kasparek, koga sam prije citirao, tvrdio je Vladi da su službenici u velikom broju ljudi koji imaju problem jer ih je emigracija odvojila od obitelji, pa se osjećaju izgubljeno u Bosni i Hercegovini. Često su postajali alkoholičari i rasipnici. ${ }^{102}$ Treba biti iskren i kazati da je, unatoč Kasparekovim preuveličavanjima, alkoholizam bio dio stvarnosti i problem među službenicima. To su znali i članovi njihovih obitelji. Jelica Belović-Bernadzikowska zapisala je u svojim memoarima da je njezin suprug Jan, sudski tajnik, bio alkoholičar ${ }^{103}$ koji je zbog te ovisnosti umro mlad ${ }^{104}$. U dosjeu cestara Josipa Huka nalazimo mišljenje njegova naređenog, koji je pisao da je ovaj pijanac i zbog toga često izbiva s posla, a ako i dođe, dolazi pijan. ${ }^{105}$

Iako su ljudi loših manira, alkoholičari i posjetitelji bordela bili mrlja na kolektivnoj biografiji službeničkoga života, većinu činovništva činili su ljudi koji su uzorno živjeli i međusobno se družili. Treba napomenuti da su prva moderna igračka društva u Bosni i Hercegovini većinom utemeljili službenici, koji su tražili načine za razonodu. Nju su našli u otvaranju službeničkih kasina, gdje su se mogli zabavljati. ${ }^{106}$ Ta kasina često su u malim gradovima bila jedina mjesta gdje se lokalna elita mogla zabavljati ${ }^{107}$, čitati tiskovine ili razgovarati s prijateljima. U Bihaću, gdje je kasino otvoren 1904., njegova uprava organizirala je koncerte, kupovala knjige, imala pretplatu na tisak. Bihaćki kasino članarinom su financirali njegovi članovi. ${ }^{108}$

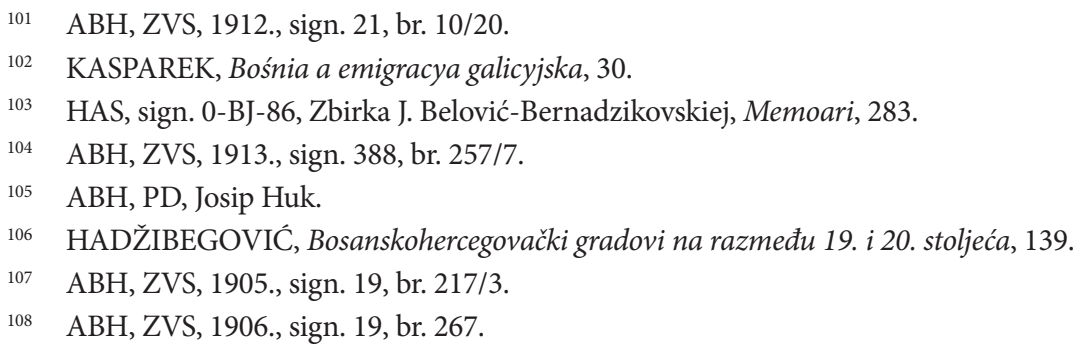


Prva društva otvorena su nekoliko godina nakon ulaska Austrijanaca u Bosnu i Hercegovinu. Često su imala nacionalni predznak, pa su postojala društva Poljaka ${ }^{109}$, Čeha ${ }^{110}$, Nijemaca ${ }^{111}$ i Mađara ${ }^{112}$. Što se tiče poljskih društava, Poljsko kolo djelovalo je manje kao nacionalno društvo, a više kao kasino i društveno središte. Jedan od voditelja Poljskoga kola, Witold Lekki, pisao je da žene onamo dolaze samo zbog muškaraca službenika. ${ }^{113}$ Osim toga postojala su društva žena, koja su djelovala u najvećim gradovima poput Mostara ${ }^{114}$ ili Sarajeva ${ }^{115}$. U Sarajevu je djelovao Herren Club, najelitniji klub u Bosni i Hercegovini, čiji su članovi bili samo najbogatiji i najvažniji pojedinci iz života Bosne i Hercegovine. ${ }^{116}$

Djelovala su i društva koja su okupljala članove prema profesiji; tako nalazimo društva učitelja ${ }^{117}$, bankara ${ }^{118}$, pa čak i konobara ${ }^{119}$. U svima njima članovi su morali platiti članarinu i ispunjavati uvjete koje je nametao društveni pravilnik. ${ }^{120}$ Djelatnost tih strukovnih društava bila je borba za bolje radne uvjete. Slijedom toga, i činovnici su imali svoje društvo - Društvo diurnista $i$ činovnika pomoćnih ureda ${ }^{121}$, kao i Činovničko društvo, koje je izdavalo svoje glasilo Činovnički list. Časopis je izlazio na njemačkom i zemaljskom jeziku, a većina članaka govorila je o pitanjima od neposrednoga interesa činovnika. Na stranicama časopisa donosila su se i stenografska izvješća sa saborskih sjednica, članci i naredbe koji su se odnosili na službenike. I časopis i društvo bili su povezani s Hrvatskom narodnom zajednicom. ${ }^{122}$

Osim druženja u okrilju kasina ili društava, službenici su rado sudjelovali u različitim sportskim aktivnostima. Vrlo popularne bile su konjske utrke, a s obzirom na veliki broj posjetitelja, to su bila jedna od prvih masovnih sportskih događanja u Bosni i Hercegovini. Vlada je 1913. donijela zakonsku regulaciju kojom je uređeno organiziranje konjskih utrka, ${ }^{123}$ a poticaj njezinoj

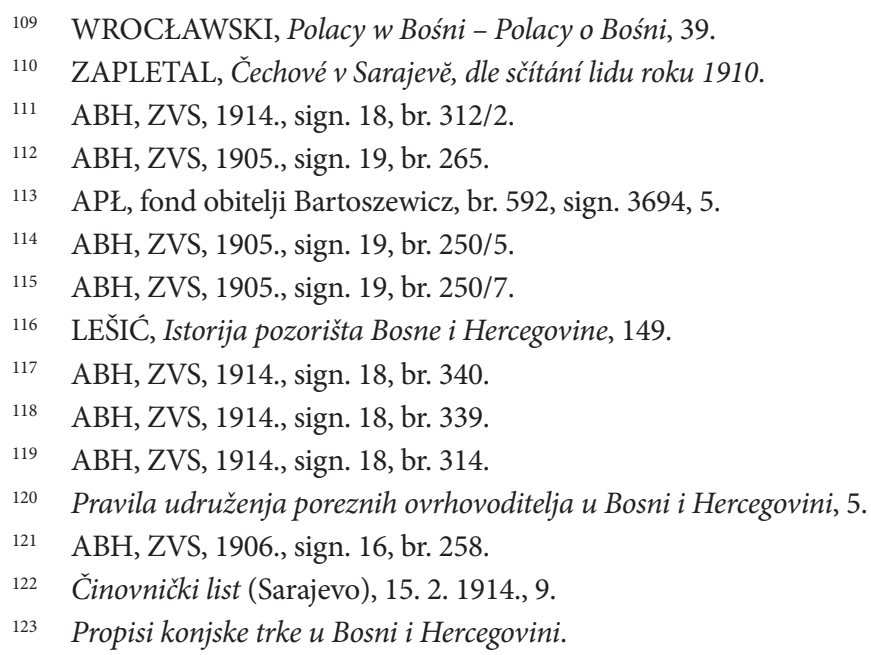


intervenciji bilo je rašireno klađenje, u kojem je sudjelovao veliki broj ljudi. Natjecateljsko razdoblje trajalo je od 1. travnja do 30. prosinca. ${ }^{124}$

Biciklizam je bio popularna sportska razonoda službenika, pa je u Sarajevu osnovano biciklističko društvo Radfahrerclub ${ }^{125}$, u Mostaru i Banjoj Luci biciklističko društvo Orao, a osnivani su i klubovi ljubitelja automobila; u Sarajevu je predsjednik toga kluba bio Poljak Kornel Mościcki. Osnivana su i pjevačka društva (npr. Muško pjevačko društvo u Sarajevu ${ }^{126}$ ).

Druga mogućnost zabave bio je lov. Mnogi pojedinci obožavali su mogućnost ubijanja divljači u šumama, a Bosna i Hercegovina, u kojoj su rasle mnoge šume, odgovarala je potrebama lovaca. Do 1893. nisu postajali zakoni o lovu; njih je uvela austrougarska vlada. Zakonom je lov zabranjen osim za pojedince s dozvolom koju je izdavala Zemaljska vlada, ${ }^{127}$ a lov je dozvoljen svugdje osim u nacionalnim parkovima, za koje je uvedena zabrana ${ }^{128}$. Priroda je jako privlačila službenike, tim više što su mnogi od njih voljeli turizam. U Sarajevu je djelovalo turističko društvo, a njegov predsjednik bio je Poljak, činovnik Josip Napadiewicz. Često su kao gosti stranih službenika dolazili njihovi prijatelji ili članovi obitelji iz drugih zemalja da bi uživali u divljoj i nedostupnoj bosanskohercegovačkoj prirodi. O tim godinama turističkoga interesa za Bosnu i Hercegovinu pisao je Ćiro Truhelka: „Prirodna je posljedica toga bila da je turistički svijet sa svih strana Evrope nagrnuo u Bosnu, da svojim očima promatra samoniklu prirodu i kulturu zemlje, koja se budi iz stoljetnog mrtvila i koja je, što se tiče turizma, ubrzo postala takmacem Švicarske i Italije."129

\section{Epilog}

Dolazak službenika promijenio je Bosnu i Hercegovinu i njezin svakodnevni život. Tijekom četrdeset godina okupacije oni su bili dio elite te zemlje napredak Bosne i Hercegovine u tom razdoblju bio je u velikoj mjeri njihov doprinos. Službenici su bili čvrsto povezani s austrougarskom vladom, pa ne čudi da se nakon propasti Monarhije 1918. većina njih osjećala kao bez pokrovitelja. Tada su se otvarale mogućnosti da se kadar popunjava domaćim ljudima, a važno je napomenuti da je u Jugoslaviji postojao dio inteligencije, posebno

\footnotetext{
$124 \quad$ Isto, 2-4.

125 HEUBERGER, „Gedenktage in Bosnien-Herzegowina”, 362.

126 „Desetogodišnjica Muškog pjevačkog društva u Sarajevu”, Nada (Sarajevo), 1897., br. 12, 238239.

127 LASKA, Lovstvo u Bosni i Hercegovini, 3-4.

128 Isto, 6.

129 TRUHELKA, Uspomene jednog pionira, 86.
} 
muslimanske, koji je bio obrazovan na sveučilištima Dvojne Monarhije. ${ }^{130} \mathrm{Tu}$ spadaju istaknuti pojedinci međuratnoga razdoblja poput Mehmeda Spahe, Hamdije Karamehmedovića, Mustafe Kadića itd. Mnogi među činovnicima bili su stranci, koji su se nakon dvadeset, trideset, pa i više godina življenja u Bosni i Hercegovini morali nakon raspada Monarhije vratiti u Poljsku, Čehoslovačku, Mađarsku. Repatrijacija je išla prema zemljama čije su državljanstvo imali, a bila je potaknuta mišljenjem da su oni politički nepouzdani za jugoslavensku državu. ${ }^{131}$ Stoga su morali napustiti Bosnu i Hercegovinu. Ipak, neki su se brzo vratili. Jedna od njih bila je Teodora Krajewska, koja se nije mogla naviknuti na Varšavu, koju je napustila 80 -ih godina XIX. stoljeća, a kada se vratila nakon Prvoga svjetskog rata, iznenadila se koliko su se Varšava i nova Poljska promijenile. To ju je potaknulo da se ubrzo vrati u Kraljevinu Srba, Hrvata i Slovenaca. Međutim, ponovo se vratila u Poljsku 1927. godine. ${ }^{132}$ Mnogi od stranaca bili su „ljudi bez doma” jer su ih u Bosni i Hercegovini držali nepouzdanima, a u novim/starim sredinama, Čehoslovačkoj, Mađarskoj ili Poljskoj, nisu se dobro osjećali. Neki mlađi strani službenici koji su se oženili lokalnim djevojkama (najčešće Hrvaticama, manje Srpkinjama, najmanje muslimankama) ostali su u Bosni i Hercegovini. Kao znak odanosti novoj državi potpisali su zakletvu novom kralju iz dinastije Karađorđevića, preuzeli novo državljanstvo i nastavili raditi; tako su postali nasljeđe austrougarskoga svijeta koji je zauvijek propao. ${ }^{133}$

\section{Zaključak}

Činovnici višega i nižega reda bili su odgovorni za provođenje svih odluka koje su donosili političari u Beču ili Sarajevu. Nakon 1879. oni su postali nova gradska elita, koja je modernizirala zemlju do kraja Prvoga svjetskog rata. Čovjek odgovoran za stvaranje moderne administracije bio je Benjamin von Kállay, koji se brinuo da broj činovnika raste. Zato im je davao mnoge privilegije koje nisu uspjeli ostvariti u drugim državama Habsburškoga Carstva. Oni su bili mostovi koji su spajali stanovnike Bosne i Hercegovine sa Zemaljskom vladom. Mnogi od njih bili su stranci, ne samo Nijemci ili Mađari, nego prije svega Slaveni: Česi, Slovaci, Poljaci. Zbog toga se Bosna i Hercegovina kao zemlja modernizirala. Promijenio se svakodnevni život zbog tehničkoga i so-

130 ALIBEGOVIĆ, „Iz kulturnog života bosansko-hercegovačkih muslimana u prošlosti”, 32-33.

131 OMEROVIĆ, Političko nasilje u Bosni i Hercegovini, 69-75.

132 LIS, ZLODI, Bosna u uspomenama Teodore Krajewske $z$ Kosmowskich, 38.

133 Mnogi službenici nižega razreda, ako su odlučili ostati u Bosni i Hercegovini, poslije su bivali promaknuti, kao geometar Robert Miączyński ili Dominik Kuczyński. ABH, PD, Robert Miaczynski; ABH, PD, Dominik Kuczynski. 
cijalnoga napretka. Službenici i njihove obitelji donijeli su „duh zapada” u orijentalnu, muslimansku zemlju. Bila je to „nova elita” koja je gradila kazališta, osnivala društva za prosvjećivanje i zabave, izdavala tisak i otvarala knjižare.

Oni nisu bili kolonisti kao Francuzi u Africi ili Englezi u Aziji. Mnogi od njih bili su mladi muškarci. Bili su neoženjeni i nakon dolaska upoznavali su domaće djevojke, pa su se ženili Hrvaticama, Srpkinjama, manje muslimankama. Tako su se asimilirali. U drugoj generaciji, njihova djeca bila su povezanija s Bosnom i Hercegovinom nego sa zemljom roditelja. S druge strane domaći ljudi uzeli su mnogo uzoraka sa zapada. Osim toga iz godine u godinu povećavao se broj domaćih službenika rođenih u Bosni i Hercegovini.

Službenici koji su radili u austrougarskoj upravi promijenili su krajolik te zemlje. Nažalost, taj mnogobrojni mozaik raspao se nakon Prvoga svjetskog rata, kada su stranci morali napustiti Balkan usprkos tome što su mnogi ondje živjeli više od trideset godina. Zbog toga su službenici, kao predstavnici austrougarskoga „dušmanina”, bili zaboravljeni ili, ako se još nešto govorilo o njima, predstavljani kao alat za gušenje nacionalnoga pokreta Južnih Slavena. Rijetko se spominje da su imali veliki utjecaj na kulturu, znanost i zabavu.

Preveli Tomasz Jacek Lis i Duje Jerković.

\section{Arhivski izvori}

ABH, GB: Bosna i Hercegovina, Arhiv Bosne i Hercegovine, Sarajevo, fond Gabinet Briefe.

ABH, PD: Bosna i Hercegovina, Arhiv Bosne i Hercegovine, Sarajevo, fond Personalni dosje.

ABH, ZVS: Bosna i Hercegovina, Arhiv Bosne i Hercegovine, Sarajevo, fond Zemaljska vlada za Sarajevo.

HAS: Bosna i Hercegovina, Historijski Arhiv Sarajeva, Sarajevo, fond Jelica Belović-Bernadzikowska.

APŁ: Poljska, Archiwum Państwowe w Łodzi [Državni arhiv u Łódźu], Łódź, fond Obitelj Bartoszewicz.

BJ, Rkps: Poljska, Biblioteka Jagiellońska, Odział Rękopisów [Jagelonska knjižnica, Odsjek za rukopisne zbirke], Kraków, fond Adam Ferens.

MNK: Poljska, Narodowe Muzeum w Krakowie [Nacionalni muzej u Krakovu], Kraków, fond Paweł Sapieha. 
HHSA, Kab.-Archiv: Haus, Hof- und Staatarchiv, Wien, fond Kab.-Archiv 1909-1911.

HHSA, Otto von Harrach: Haus, Hof- und Staatarchiv, Wien, Familie Archiv Harrach, fond Otto von Harrach.

\section{Tisak}

Bosanski glasnik (Sarajevo), 1915.

Činovnički list (Sarajevo), 1914.

Nada (Sarajevo), 1897.

Narodno jedinstvo (Sarajevo), 1919.

Reforma Urzędnicza (Lwów), 1912-1913.

Urzędnik (Przemyśl), 1880.

\section{Objavljeni izvori}

Bericht über die Verwaltung von Bosnien und der Hercegovina 1907. Wien, 1907.

Bericht über die Verwaltung von Bosnien und der Hercegovina 1908. Wien, 1908.

Bericht über die Verwaltung von Bosnien und der Hercegovina für die Jahre 1914-1917. Wien, 1917.

Bošnjak. Kalendar za prostu godinu 1902. Sarajevo, 1902.

Bošnjak. Zvanični kalendar za prostu godinu 1914. Sarajevo, 1914.

CZECH, Józef. Kalendarz krakowski na rok 1907. Kraków: Wydawnictwo „Czasu”, 1907.

CZERMIŃSKI, Marcin. Z podróży po Bośni i Hercegowinie. Kraków: Wydawnictwo „Czasu”, 1899.

Glasnik zakona i naredaba za Bosnu i Hercegovinu, 1885-1907.

JUZBAŠIĆ, Dževab; ŠEHIĆ, Zijad, ur. Lične zabilješke generala Oskara Potioreka o unutrašnjopolitičkoj situaciji u Bosni i Hercegovini. Sarajevo: Akademija nauka i umjetnosti Bosne i Hercegovine, 2015.

KASPAREK, Teodor. Bośnia a emigracya galicyjska. Lwów: Nakładem autora, 1903.

Kronika Uniwersytetu Jagiellońskiego od 1884 do 1887 roku. Kraków: Drukarnia Uniwersytetu Jagiellońskiego, 1887. 
LASKA, Fr. B. Lovstvo u Bosni i Hercegovini i tamošnji državni rezervati za divljač. Sarajevo, 1904 [pretisak: Sarajevo: Udruženje inženjera i tehničara šumarstva Federacije $\mathrm{BiH}, 2009]$.

LEŠIĆ, Josip. Istorija pozorišta Bosne i Hercegovine. Sarajevo: Svjetlost, 1985.

LIS, Tomasz Jacek; ZLODI, Zdravka. Bosna u uspomenama Teodore Krajewske z Kosmowskich (1854-1935). Zagreb: Hrvatski institut za povijest, 2015.

MAGIERA, Jan. Ludność Polska w Bośni. Kraków: Księgarnia literacka Karola Kwaśniewskiego, 1912.

PAUL, Otto. Bericht über die Tätigkeit des Institutes für bosnisch-hercegowinische Hochschüler in Wien in den ersten zehn Jahren seines Bestandes (Studienjahre 1899/1900 bis 1908/1909). Wien: Adolf Holzhausen, 1910.

PFEFFER, Leo. Istraga u sarajevskom atentatu. Zagreb: Nova Evropa, 1938.

Pravila udruženja poreznih ovrhovoditelja u Bosni i Hercegovini. Prijedor: Štamparija Nikodima Mijatovića, 1912.

Propisi konjske trke u Bosni i Hercegovini. Sarajevo: Zemaljska štamparija, 1913.

Spomenica o 25. godišnjici postojanja Sveučilišta Franje Josipa I. u Zagrebu. Zagreb: Akademički senat Kr. sveučilišta, 1900.

STARZYŃSKI, Stanisław. Historya Uniwersytetu Lwowskiego 1869-1894. Lwów: Senat Akademicki Uniw. Lwowskiego, 1894.

ŠIDAK, Jaroslav. Spomenica u povodu proslave 300-godišnjice Sveučilišta u Zagrebu. Zagreb: Sveučilište, 1969.

TRUHELKA, Ćiro. Uspomene jednog pionira. Zenica: Vrijeme, 2012.

VALOUŠEK, František. Sjećanja na Bosnu. Zapisi austrougarskog žandara na službi u Bosni. Sarajevo: Bosanska riječ, 2016.

\section{Literatura}

ALIBEGOVIĆ, Esadbeg. „Iz kulturnog života bosansko-hercegovačkih muslimana u prošlosti”. Glasnik Vrhovnog islamskog starješinstva (1971), br. 7-8: 31-37.

BACZKOWSKI, Michał. „Prostytucja w Krakowie na przełomie XIX i XX wieku”. Studia Historyczne (2000), br. 4: 593-607.

BANACH, Andrzej Kazimierz. Kariery zawodowe studentów Uniwersytetu Jagiellońskiego pochodzenia chłopskiego z lat 1860/1861-1917/1918. Kraków: Księgarnia Akademicka, 2009. 
BUJAK, Franciszek. Galicya, vol. 1. Kraków: Księgarnia Altenberga, 1908.

DONIA, Robert J. Islam under the Double Eagle: The Muslims of Bosnia and Herzegovina, 1878-1918. New York: East European Quarterly, 1981.

DONIA, Robert J. Sarajevo: A Biography. Michigan: University of Michigan Press, 2006.

DYBIEC, Julian. „Galicja na drodze do wielkiej przemiany”. U: Kraków i Galicja wobec przemian cywilizacyjnych (1866-1914), ur. Fiołek Krzysztof i Stala Marian. Kraków: Universitas, 2011., 31-42.

DŽAJA, Srećko. Bosna i Hercegovina u austrougarskom razdoblju (18781918). Inteligencija izmedu tradicije i ideologije. Mostar; Zagreb: Ziral, 2002.

ĐAKOVIĆ, Luka. Političke organizacije bosanskohercegovačkih katolika Hrvata, I. dio: Do otvaranja Sabora 1910. Zagreb: Globus, 1985.

GLUCK, Władysław. Sarajewo (historia zamachu sarajewskiego). Kraków: Gebethner i Wolff, 1935.

GROSS, Mirjana. „Hrvatska politika u Bosni i Hercegovini od 1878 do 1914". Historijski zbornik 19-20 (1967-1968): 9-73.

HADŽIBEGOVIĆ, Ilijas. Bosanskohercegovački gradovi na razmeđu 19. i 20. stoljeća. Sarajevo: Institut za istoriju, 2004.

HADŽIBEGOVIĆ, Ilijas. „Migracije stanovništva u Bosni i Hercegovini”. Prilozi Instituta za istoriju u Sarajevu (1975-1976), br. 11-12: 310-317.

HADŽIBEGOVIĆ, Ilijas. Postanak radničke klase u BiH i njen razvoj do 1914. Sarajevo: Svjetlost, 1980.

HADŽISELIMOVIC, Omer. „Na vratima Istoka: engleski putnici u Bosni i Hercegovini od 16 do 20 veka”. Zgodovinski časopis 45, (1992), br. 1: 160-162.

HAUPTMANN, Ferdo. „Privreda i društvo Bosne i Hercegovine u doba austrougarske vladavine (1878-1918)". Prilozi za istoriju Bosne i Hercegovine, ANUBiH, Posebna izdanja, knj. 18 (1987), 99-211.

HEINDL, Waltraud. Josephinische Mandarine: Bürokratie und Beamte in Österreich, vol. 2: 1848-1914. Wien: Böhlau, 2013.

HEUBERGER, Valeria. „Gedenktage in Bosnien-Herzegowina”. U: Der Kampf um das Gedächtnis: Öffentliche Gedenktage in Mitteleuropa, ur. Brix Emil i Stekl Hannes. Wien; Köln: Böhlau, 1997., 355-376.

JUZBAŠIĆ, Dževad. Politika i privreda u Bosni i Hercegovini pod austrougarskom upravom. Sarajevo: Akademija nauka i umjetnosti Bosne i Hercegovine, 2002. 
KALUĐERČIĆ, Stevan. „Srbi i Srpkinje iz Vojvodine učitelji i učiteljice u Bosni i Hercegovini”. Glasnik Istorijskog društva u Novom Sadu (1939), br. 12: 193-209.

KAMBEROVIĆ, Husnija. Begovski zemljišni posjedi u Bosni i Hercegovini od 1878 do 1918. Sarajevo: Ibn Sina, 2005.

KASUMOVIĆ, Amila. „Prilog povijesti marginalnih skupina u Bosni i Hercegovini u doba austro-ugarske uprave: prostitutke”. Historijski zbornik 60 (2007): 161-178.

KRALJAČIĆ, Tomislav. Kalajev režim u Bosni i Hercegovini: 1882-1903. Sarajevo: Veselin Masleša, 1987.

KREŠEVLJAKOVIĆ, Hamdija. Sarajevo za vrijeme austrougarske uprave 1878-1918. Sarajevo: Arhiv grada, 1969.

KRZYK, Tomislav. Česi u Sarajevu 1878-2010. Sarajevo: Matica hrvatska, 2015.

LIS, Tomasz Jacek. „Bosna i Hercegovina u očima Poljaka - poljski putopisi o Bosni i Hercegovini u austrougarskom razdoblju”. Prilozi 47 (2018): 91-105., Sarajevo.

OKEY, Robin. Taming Balkan Nationalism: The Habsburg „Civilizing Mission” in Bosnia, 1878-1918. Oxford: Oxford University Press, 2007.

OMEROVIĆ, Enes. Političko nasilje u Bosni i Hercegovini (1918-1921). Sarajevo: Institut za istoriju, 2015.

PALAIRET, Michael. „The Habsburg Industrial Achievement in Bosnia-Hercegovina, 1878-1914: An Economic Spurt That Succeeded?”. Austrian History Yearbook 24 (1993): 133-152.

PAPIĆ, Mitar. Školstvo u Bosni i Hercegovini za vrijeme austrougarske okupacije (1878-1918). Sarajevo: Veselin Masleša, 1972.

PINTO, Avram. Jevreji Sarajeva i Bosne i Hercegovine. Sarajevo: Veselin Masleša, 1987.

PULJIĆ, Borislav; ŠETKA PRLJIĆ, Mirela; RAKIĆ, Marija. „Arhitekti i graditelji u Mostaru za vrijeme Austro-Ugarske Monarhije (1878-1918)”. Prostor. Znanstveni časopis za arhitekturu i urbanizam 25 (2017), br. 1 (53): 2-19.

RÖSKAU-RYDEL, Isabel. Niemiecko-austriackie rodziny urzędnicze $w$ Galicji 1772-1918. Kraków: Wydawnictwo Naukowe Uniwersytetu Pedagogicznego, 2011.

RUBACHA, Jarosław; MALINOWSKI, Andrzej; GIZA, Antoni. Historia Bułgarii 1870-1915. Warszawa: Neriton, 2006. 
SCHMID, Ferdinand. Bosnien und die Herzegovina unter der Verwaltung Österreich-Ungarns. Leipzig: Veit \& Comp., 1914.

SLADOVIĆ SLADOEVIČKI, Eugen. Upravna nauka i upravno pravo Bosne i Hercegovine. Sarajevo: Zemaljska vlada za Bosnu i Hercegovinu, 1916.

SOBOŃ, Marcin. Polacy wobec Żydów w Galicji dobry autonomicznej w latach 1868-1914. Kraków: Vesro, 2011.

SUGAR, Peter F. Industrialization of Bosnia-Hercegovina, 1878-1918. Seattle: University of Washington Press, 1963.

ŠAMIĆ, Midhat. Francuski putnici u Bosni na pragu XIX stoljeća i njihovi utisci o njoj. Sarajevo: Veselin Masleša, 1966.

TAHIROVIĆ, Husref; FUCHS, Brigitte. „Bogusławą Keckova: An Official Female Doctor in Bosnia and Hercegovina, 1893-1911". Acta Medica Academica 48 (2019), br. 2: 232-249.

TAUBER, Eli. Jevrejska štampa u BiH 1900-2011. Sarajevo: Mediacentar; La Benevolencija, 2011.

WROCŁAWSKI, Krzysztof, ur. Polacy w Bośni - Polacy o Bośni. Przewodnik bibliograficzny z komentarzami. Warszawa: Wydawnictwo Uniwersytetu Warszawskiego, 2003.

ZAPLETAL, Josef. Čechové v Sarajevĕ, dle sčítání lidu roku 1910. Sarajevo: Česka beseda, 1913.

ŽMIRIĆ, Amira. Austrijski i njemački putopisi o Bosni i Hercegovini do 1941 godine. Banja Luka: Besjeda, 2012. 


\section{SUMMARY}

\section{Officials in Bosnia and Herzegovina during the 1878-1918 Period}

In my article, I would like to present the development of the civil administration in Bosnia and Herzegovina in the late $19^{\text {th }}$ and early $20^{\text {th }}$ century. This interesting issue is seldom examined in historiography. One can often read opinions that the Austro-Hungarian officials in Bosnia and Herzegovina were similar to the French or British colonial administration in African or Asian countries. On the other hand, Yugoslav, or sometimes post-Yugoslav, historians assert that Austro-Hungarian officials were the tools of a repressive policy. My goal is to carefully analyse this problem using archival sources from Bosnia, Poland, and Austria. Research reveals that said officials were not only of Austrian and Hungarian nationality, but there were also many Slavs among them. I shall also examine the cultural and social contribution of the new elite, which was composed of these officials.

Key words: Bosnia and Herzegovina; Austro-Hungarian occupation; officials; Common Ministry of Finance; Land Government in Sarajevo 